\title{
Temperature Thresholds and Thermal Requirements for Development and Survival of Dysmicoccus brevipes (Hemiptera: Pseudococcidae) on Table Grapes
}

\author{
A BeRTIN ${ }^{1} \odot$, S LERIN ${ }^{2}$, M BOTTON $^{3}$, JRP PaRRA $^{1}$ \\ ${ }^{1}$ Depto de Entomologia e Acarologia, Univ de São Paulo, Piracicaba, SP, Brasil \\ ${ }^{2}$ Instituto Federal de Educação, Ciência e Tecnologia do Rio Grande Do Sul, Bento Gonçalves, RS, Brasil \\ ${ }^{3}$ Embrapa Uva e Vinho, Bento Gonçalves, RS, Brasil
}

\section{Keywords}

Pineapple mealybug, Vitis vinifera, thermal constant, lower developmental threshold, optimal temperature

\section{Correspondence \\ A Bertin, Depto de Entomologia e Acarologia, Univ de São Paulo, Avenida Pádua Dias 11, CP 9, Piracicaba, SP13418- 900, Brasil; aline.bertin@usp.br \\ Edited by Leandro P Ribeiro - EPAGRI \\ Received 15 February 2018 and accepted 10 July 2018 \\ (C) Sociedade Entomológica do Brasil 2018}

\begin{abstract}
Temperature is an important climate factor that has a direct influence on insect biology and consequently a crucial role in forecasting and integrated pest management. The mealybug Dysmicoccus brevipes (Cockerell) (Hemiptera: Pseudococcidae) is one of the most common species in Brazilian vineyards. Here, development and survival of $D$. brevipes on leaves of table grapes (Vitis vinifera cv. Itália) were studied at five constant temperatures $\left(15,20,25,28\right.$, and $\left.30 \pm 1^{\circ} \mathrm{C}\right)$ under laboratory conditions. We investigated the developmental time and nymphal survival, temperature thresholds, and the degree-day requirements for each life stage of $D$. brevipes. The developmental time for the nymphal stage ranged from 32 to 130 days with decreasing the temperature, with the temperatures of 28 and $30^{\circ} \mathrm{C}$ providing the shorter developmental time. Survival of the entire nymphal stage was affected by the temperature, ranging from $81 \%$ at $20^{\circ} \mathrm{C}$ to $1 \%$ at $15^{\circ} \mathrm{C}$. The predicted upper lethal temperature was $34.5^{\circ} \mathrm{C}$, while the optimal temperature was $28.6^{\circ} \mathrm{C}$. The minimum threshold for total development of $D$. brevipes occurred at $8.2^{\circ} \mathrm{C}$. Dysmicoccus brevipes required 678.4 degree-days to complete development from first-instar nymph to adult. The temperature of $30^{\circ} \mathrm{C}$ was the most suitable for the development of $D$. brevipes. The thermal thresholds estimated for $D$. brevipes life cycle suggest that this species can develop in different table grape-producing regions of Brazil, in a temperature range between 8 and $35^{\circ} \mathrm{C}$.
\end{abstract}

\section{Introduction}

Pineapple mealybug, Dysmicoccus brevipes (Cockerell) (Hemiptera: Pseudococcidae), is one of the most common mealybugs in the Neotropical region. In spite of its common name, $D$. brevipes occurs on a wide variety of plants (Williams \& Granara de Willink 1992), infesting roots, leaves, and fruits (Ben-Dov 1994, Santa-Cecília et al 2007). In vineyards, similar to other mealybugs that are found in the crop, $D$. brevipes causes direct crop loss and gradual weakening of vines (Daane et al 2012) by feeding on roots, leaves, and grape clusters. In the latter case, contamination causes cosmetic damage to clusters, due to the excreted honeydew that covers the bunches and leaves and results in sooty-mold growth (Flaherty et al 1992, González \& Volosky 2004, Daane et al 2008 , 2012). In Brazil, D. brevipes is one of the most common mealybug species infesting vines and weeds in vineyards (Morandi Filho et al 2015, Pacheco da Silva et al 2014, 2017). Its presence is associated with reduced marketability of table grapes, which can also compromise international trade due to quarantine restrictions (Daane et al 2012).

Despite the economic damage caused by $D$. brevipes, the effects of biotic and abiotic factors on the development of the species remain relatively unexplored, 
especially on grapevines. Among the abiotic factors, temperature is a determinant for the development of mealybugs (Varikou et al 2010, Daane et al 2012). Knowledge of the thermal requirements for $D$. brevipes development is essential to estimate the seasonal occurrence of the pest in vineyards, its potential growth in different producing regions, and population outbreaks. This is even more important in view of the expansion of grapevine cultivation to different regions of Brazil, especially those in a tropical region (Protas 2016), and the impact of climatic changes on insect populations (Robinet \& Roques 2010, Ju et al 2015).

Given that population outbreaks and spread to new production regions can be facilitated by environmental changes, it is essential to understand how populations respond to different thermal conditions and more specifically how they affect life-history traits. To address this, we studied the effect of different temperatures on the development and survival of $D$. brevipes on table-grape leaves and estimated the temperature range for physiological development. This information will help predict the distribution and occurrence of the pest and to develop strategies for integrated pest management.

\section{Material and Methods}

\section{Maintenance of insect colony and host plants}

A colony of $D$. brevipes was initiated in May 2008 using adult females originally collected from roots of infested figs (Ficus carica). The colony was maintained on squash plants (Cucurbita maxima $\times$ Cucurbita moschata cv. Cabotiá) in controlled conditions $\left(25 \pm 2^{\circ} \mathrm{C}, 70 \pm 10 \% \mathrm{RH}\right.$, and a photoperiod of $14 \mathrm{~L}: 10 \mathrm{D} \mathrm{h}$ ).

To determine the thermal requirements of $D$. brevipes, gravid adult females from the laboratory colony were isolated in petri dishes (diam. $6.0 \mathrm{~cm}$ ) containing a layer $(1 \mathrm{~cm})$ of $3 \%$ agar-water and table-grape leaf discs (diam. $3.5 \mathrm{~cm}$ ) until oviposition. After oviposition, first-instar nymphs ( $<24 \mathrm{~h}$ old) were individually transferred to table-grape leaf discs (diam. $3.5 \mathrm{~cm}$ ) (Vitis vinifera cv. Itália) in petri dishes (diam. $4.5 \mathrm{~cm}$ ) containing a layer $(1 \mathrm{~cm})$ of $3 \%$ agar-water. The table-grape leaves were collected in Bento Gonçalves, Rio Grande do Sul, in vineyards free from insecticide applications. Mealybugs were transferred to new leaves every 5 days to ensure a supply of fresh food.

\section{Developmental time and nymph survival}

Experiments were conducted in incubators at temperatures of $15,20,25,28$, and $30 \pm 1^{\circ} \mathrm{C}, 70 \pm 10 \% \mathrm{RH}$ and a photoperiod of $14 \mathrm{~L}: 10 \mathrm{D} \mathrm{h}$, with 100 replicates in each temperature.
The developmental progress was checked every 2 days under a binocular microscope, and the different instars were distinguished based on the occurrence of molted exuviae. The sex of individual mealybugs could not be determined in the crawler stage, so replicates were composed of individuals of unknown sex until the second instar, when males develop a cocoon to complete their development (McKenzie 1967). The developmental time and survival rates of each stage and of the entire nymphal stage of $D$. brevipes were recorded. For survival rates, the values reported were calculated based on the number at the beginning and end of each stage.

\section{Temperature thresholds and degree-day calculation}

The lower developmental threshold $\left(\mathrm{T}_{\mathrm{T}}\right)$ and the thermal constant $(K$, in degree-days) of $D$. brevipes in different developmental stages were estimated by a linear regression $(y=a+$ $b T)$ that describes the relationship between temperature and developmental rate, where $y$ is the rate of development at temperature $T$, and $a$ and $b$ are the intercept and the slope, respectively (Haddad \& Parra 1984). The lower developmental threshold was given by $-a / b$, and the number of degree-days required to complete development was calculated from the reciprocal of the slope of the regression line $(1 / b)$.

The upper developmental threshold $\left(T_{\max }\right)$ and the optimal temperature $\left(T_{\text {opt }}\right)$ were estimated with the non-linear model of Logan et al (1976). Developmental rates of each stage were adjusted to the model $[1 / D=\psi[\exp (\rho T)-$ $\left.\exp \left(\rho T_{\max }-\left(T_{\max }-T / \Delta T\right)\right)\right]$, and the parameters $\left(\psi, \rho, T_{\max }\right.$ and $\Delta T)$ were estimated by the non-linear regression, where $T$ is the rearing temperature $\left({ }^{\circ} \mathrm{C}\right), \psi$ is the maximum developmental rate, $\rho$ is a constant defining the rate at optimal temperature, $T_{\max }$ is the lethal maximum temperature, and $\Delta T$ is the difference between the optimum developmental temperature and the maximum lethal temperature (Logan et al 1976). The optimal temperature $\left(T_{\mathrm{opt}}\right)$ was estimated as follows: $T_{\max }-\Delta T$ (Roy et al 2002).

The numbers of $D$. brevipes generations (NG) in different table grape-producing regions of Brazil were estimated based on the annual mean temperature of the main producing regions and the thermal requirements of the species. The main producing regions considered were as follows: (i) from temperate areas: Bento Gonçalves, Caxias do Sul (Rio Grande do Sul state), and Marialva (Paraná state); (ii) from tropical areas: Jales (São Paulo state) and Petrolina (Pernambuco state). We considered a generation to be the duration of the nymphal period plus the pre-oviposition period. The pre-oviposition period was standardized at 33 days, based on the mean value obtained at $25^{\circ} \mathrm{C}$ (Bertin et al 2013). The calculations were based on the following formula (modified from Groth et al 2017):NG $=\frac{T}{\left(\frac{K}{T_{\mathrm{m}-T_{T}}}\right)+P O}$, where $T$ is the time considered in a year (days), $T_{\mathrm{m}}$ is the annual mean 
temperature of the main producing regions, $T_{\mathrm{T}}$ is the lower developmental threshold, $K$ is the thermal constant, and $P O$ is the standardized value of the pre-oviposition period.

\section{Data analysis}

Developmental time and survival of immature stages were analyzed by fitting a generalized linear model (GLM) with the Imes package (Bates et al 2015). Developmental time was analyzed using a "quasi-Poisson" distribution and survival using a logistic regression (logit link function) with a binomial distribution. The residuals were tested for normality after GLM. Comparisons (Tukey test, $\alpha=0.05$ ) between temperatures were done with the glht function from the multcomp package (Hothorn et al 2008). All analyses were performed in the software $R$ version 3.2.0 ( $R$ Core Team 2016).

\section{Results}

No males were observed among the individual nymphs on the vine leaves, regardless of the temperature at which the insects were maintained, indicating the occurrence of thelytokous parthenogenesis. Unless otherwise stated, differences in developmental time and survival rate were significant (all $P<0.001$ ) among the tested temperatures. In the first instar, the longest developmental time was observed at $15^{\circ} \mathrm{C}$ (Table 1). There was a significant difference in developmental time at 15 and $20^{\circ} \mathrm{C}$ when compared to the warmest temperatures (Table 1). In the second instar, the developmental time at $15^{\circ} \mathrm{C}$ was significantly different from the other temperatures (Table 1), whereas at the temperatures of 20 , 25 , and $28^{\circ} \mathrm{C}$, there was no difference in this stage, and the developmental time stabilized above $28^{\circ} \mathrm{C}$. In the third instar, development at the warmest two temperatures was significantly faster compared with that at the two cooler temperatures, 20 and $25^{\circ} \mathrm{C}$ (Table 1). The developmental time of the third instar at $15^{\circ} \mathrm{C}$ was based on only one surviving individual, which was not included in the statistical analysis (Table 1). The mean duration of the nymphal period of $D$. brevipes was inversely related to the increase in temperature, and approximately $92 \%$ of the reduction in developmental time was explained by the increase in temperature (Table 1). The duration of the nymphal stage ranged from 32 $\left(28^{\circ} \mathrm{C}\right)$ to 130 days $\left(15^{\circ} \mathrm{C}\right)$ (Table 1$)$.

Temperature also influenced $D$. brevipes survival. In the first instar, survival ranged from 96 to $99 \%$ at temperatures of 20 to $30^{\circ} \mathrm{C}$, while at $15^{\circ} \mathrm{C}$, only $74 \%$ of the nymphs survived (Table 1). In the second instar, the survival of the nymphs maintained at 15 and $28^{\circ} \mathrm{C}$ decreased, while at temperatures of 20,25 , and $30^{\circ} \mathrm{C}$, survival was higher than $94 \%$ (Table 1 ). The temperature of $15^{\circ} \mathrm{C}$ significantly affected the survival of third-instar nymphs, resulting in a mortality of $95 \%$. Survival of this instar was also reduced at 25 and $28^{\circ} \mathrm{C}$, whereas at 20 and $30^{\circ} \mathrm{C}$, the highest survival percentages were observed (Table 1). Survival of individuals during the total nymphal stage was significantly affected by the temperature, ranging from $81 \%$ at $20^{\circ} \mathrm{C}$ to $1 \%$ at $15^{\circ} \mathrm{C}$ (Table 1 ).

The lower developmental threshold $\left(T_{\mathrm{T}}\right)$ for the life cycle (nymph adult) of $D$. brevipes was $8.2^{\circ} \mathrm{C}$, while for first-, second-, and third-instar nymphs, the base temperature varied between 8 and $9^{\circ} \mathrm{C}$ (Table 2, Fig 1). Based on the temperature threshold, $D$. brevipes needs 678.4 degree-days to complete its development (Table 2). The upper developmental threshold $\left(T_{\max }\right)$ and optimal temperature $\left(T_{\mathrm{opt}}\right)$ for the entire development of $D$. brevipes were estimated at $34.5^{\circ} \mathrm{C}$ and $28.6^{\circ} \mathrm{C}$, respectively (Table 3 , Fig 1 ). Based on the annual mean temperature and the lower developmental threshold, the estimated number of annual generations of $D$. brevipes for the main table grape-producing regions in Brazil ranged from 3 to 5 generations per year (Table 4).

\section{Discussion}

Temperature is considered the most significant environmental factor influencing insect development, survival, behavior, and distribution. The developmental response of insects to temperature can help to predict their occurrence and therefore assist in monitoring and control strategies for pests. In this study, development and survival of $D$. brevipes on table grapes were significantly influenced by temperature. Development and survival of $D$. brevipes were favored at the temperature of $30^{\circ} \mathrm{C}$, where a higher nymphal survival and a lower developmental time were observed. The developmental time increased as the temperature decreased; however, only $1 \%$ of the nymphs survived the lowest temperature studied.

The duration of the second and third instars and the nymphal stage of $D$. brevipes stabilized at $\geq 28^{\circ} \mathrm{C}$. The developmental time of the nymphal stage showed an inverse relationship to temperature increase, varying from 32 to 130 days with the decrease in temperature. The difference in the developmental time of $D$. brevipes between extremes of temperature was also reported when the life cycle of the species was studied in pineapple, where it ranged from 29 to 58 days at 30 and $20^{\circ} \mathrm{C}$, respectively (Colen et al 2000).

Survival of the immature stages of $D$. brevipes was also significantly affected by the temperature. Mortality of the nymphal stage at $15^{\circ} \mathrm{C}$ reached approximately $99 \%$; however, under natural conditions, mealybugs are not subjected to constant temperatures and can protect themselves in more suitable microclimates, such as under the bark of the trunk, between leaves, and in bunches of grapes, enabling them to develop even at lower temperatures (Geiger \& Daane 2001). Survival at $28^{\circ} \mathrm{C}$ also decreased after the first instar, which 
Table 1 Developmental time ( \pm SE, days) and survival rate ( \pm SE, \%) for each developmental stage of Dysmicoccus brevipes on leaves of "Itália" table grapes (Vitis vinifera), at constant temperatures of $15,20,25,28$, and $30^{\circ} \mathrm{C}(70 \pm 10 \% \mathrm{RH}$ and photophase of $14 \mathrm{~h})$.

\begin{tabular}{|c|c|c|c|c|}
\hline \multirow[t]{2}{*}{ Temperature $\left({ }^{\circ} \mathrm{C}\right)$} & \multicolumn{4}{|c|}{ Developmental time (days) } \\
\hline & First instar $(n)$ & Second instar & Third instar & Nymphal stage \\
\hline 15 & $51.68 \pm 1.18 d^{*}(64)$ & $41.11 \pm 1.98$ c (17) & $45.00 \pm 0.00^{a}(1)$ & $130.00 \pm 0.00^{a}(1)$ \\
\hline 20 & $17.27 \pm 0.36$ c (85) & $11.81 \pm 0.40 \mathrm{~b}(85)$ & $17.69 \pm 0.68$ b (73) & $47.24 \pm 1.04 \mathrm{c}(75)$ \\
\hline 25 & $11.70 \pm 0.34 a b(97)$ & $11.75 \pm 0.35$ b (9o) & $19.48 \pm 1.01$ b (56) & $42.58 \pm 1.41 \mathrm{~b}(56)$ \\
\hline 28 & $10.32 \pm 0.35$ a (53) & $9.73 \pm 0.77 \mathrm{ab}(23)$ & $11.25 \pm 1.43$ a (12) & $32.33 \pm 1.65$ a $(12)$ \\
\hline 30 & $12.83 \pm 0.25$ b (99) & $8.80 \pm 0.40$ a $(92)$ & $11.55 \pm 0.61 \mathrm{a}(72)$ & $32.95 \pm 0.94$ a $(72)$ \\
\hline$F(d f)$ & $919(4)$ & $155.79(4)$ & $23.89(3)$ & $35.90(3)$ \\
\hline \multirow[t]{2}{*}{$P$ value } & $<0.001$ & $<0.001$ & $<0.001$ & $<0.001$ \\
\hline & Survival rate (\%) & & & \\
\hline 15 & $74.72 \pm 4.58 a^{*}(91)$ & $23.25 \pm 4.58$ a (86) & $5.00 \pm 0.00^{\mathrm{a}}(20)$ & $1.09 \pm 0.00^{a}(91)$ \\
\hline 20 & $96.84 \pm 1.80 \mathrm{~b}(95)$ & $97.77 \pm 1.56$ b (9o) & $90.58 \pm 3.18$ b (85) & $81.05 \pm 4.04 \mathrm{c}(95)$ \\
\hline 25 & $98.97 \pm 1.02$ b (98) & $98.93 \pm 1.06$ b (94) & $62.22 \pm 5.13$ a (90) & $57.14 \pm 5.02$ b (98) \\
\hline 28 & $98.11 \pm 1.88$ b (53) & $45.28 \pm 6.90$ a $(53)$ & $50.00 \pm 10.42$ a (24) & $22.64 \pm 5.80$ a (53) \\
\hline 30 & $99.00 \pm 1.00 \mathrm{~b}(100)$ & $94.94 \pm 2.21$ b (99) & $83.90 \pm 3.96$ b (87) & $73.00 \pm 4.46 \mathrm{bc}(100)$ \\
\hline $\mathrm{F}(d f)$ & $12.74(4)$ & $54.53(4)$ & $10.29(3)$ & $18.62(3)$ \\
\hline$P$ value & $<0.001$ & $<0.001$ & $<0.001$ & $<0.001$ \\
\hline
\end{tabular}

*Means ( \pm SE) within each column followed by the same letters are not significantly different according to the Tukey test $(P<0.05)$.

${ }^{a}$ Data not included in the statistical analysis due to the absence of replicates.

would be unexpected, since the temperature of $28^{\circ} \mathrm{C}$ was the optimal temperature estimated by the non-linear model. We can not rule out the possibility of a problem with our incubator during the experiment, even though the temperature was checked daily. A sudden rise in temperature, even for a few hours, could have caused the death of the mealybugs.

Based on the life-cycle duration and viability, the temperature of $30^{\circ} \mathrm{C}$ was the most favorable for the development of $D$. brevipes. At $30^{\circ} \mathrm{C}$, developmental time was shorter and survival of nymphs was higher, indicating that $D$. brevipes could survive and develop in tropical regions (Williams \& Granara de Willink 1992). As for D. brevipes, the development and survival of Planococcus ficus (Signoret) (Hemiptera: Pseudococcidae) on table grapes were also favored by the constant temperature of $30^{\circ} \mathrm{C}$ (Varikou et al 2010). The lower developmental threshold estimated for the biological cycle of $D$. brevipes, as well as the upper developmental threshold, suggests that the species can survive and develop in the different table grape-producing regions in Brazil, because the thermal range for development is quite broad. Temperatures higher than the upper developmental threshold can occur in the different table grapeproducing regions in Brazil; however, as mentioned before, mealybugs have the ability to shelter in more-suitable microclimates (Geiger \& Daane 2001).

In addition to temperature, inherent characteristics of the species and the nutritional quality of the host plant on which the insects were maintained can affect their thermal constants (Bergant \& Trdan 2006). This is evident when the lower developmental threshold of $D$. brevipes on vines is compared to those obtained when the insect was reared on pineapple, where the values for first, second, and third instars and nymphal period of females (13.9, 6.1, 2.5, and $9.5^{\circ} \mathrm{C}$, respectively) differ from our work (Colen et al 2000),

Table 2 Linear regression equation of the developmental rate, coefficient of determination $\left(R^{2}\right)$, lower developmental threshold $\left(T_{T}\right)$, and thermal constant $(K)$, for each developmental stage of Dysmicoccus brevipes on leaves of Itália table grapes (Vitis vinifera), at temperatures of 15, 20, 25, 28, and $30^{\circ} \mathrm{C}(70 \pm 10 \% \mathrm{RH}$ and photophase of $14 \mathrm{~h})$.

\begin{tabular}{|c|c|c|c|c|c|}
\hline $\begin{array}{l}\text { Developmental } \\
\text { stage }\end{array}$ & $\begin{array}{l}\text { Linear regression } \\
\text { equation }\end{array}$ & $R^{2}$ & $T_{\mathrm{T}}\left({ }^{\circ} \mathrm{C}\right)$ & $\begin{array}{l}\text { K (degree- } \\
\text { days) }\end{array}$ & $P$ value \\
\hline First-instar nymph & $Y=-0.03853+0.00447 x$ & 0.8208 & 8.61 & 223.51 & 0.034 \\
\hline Second-instar nymph & $Y=-0.04230+0.00508 x$ & 0.8553 & 8.31 & 196.57 & 0.024 \\
\hline Third-instar nymph & $Y=-0.03790+0.00413 x$ & 0.8667 & 9.16 & 241.77 & 0.021 \\
\hline Nymphal stage & $Y=-0.01208+0.00147 x$ & 0.9253 & 8.2 & 678.42 & 0.008 \\
\hline
\end{tabular}



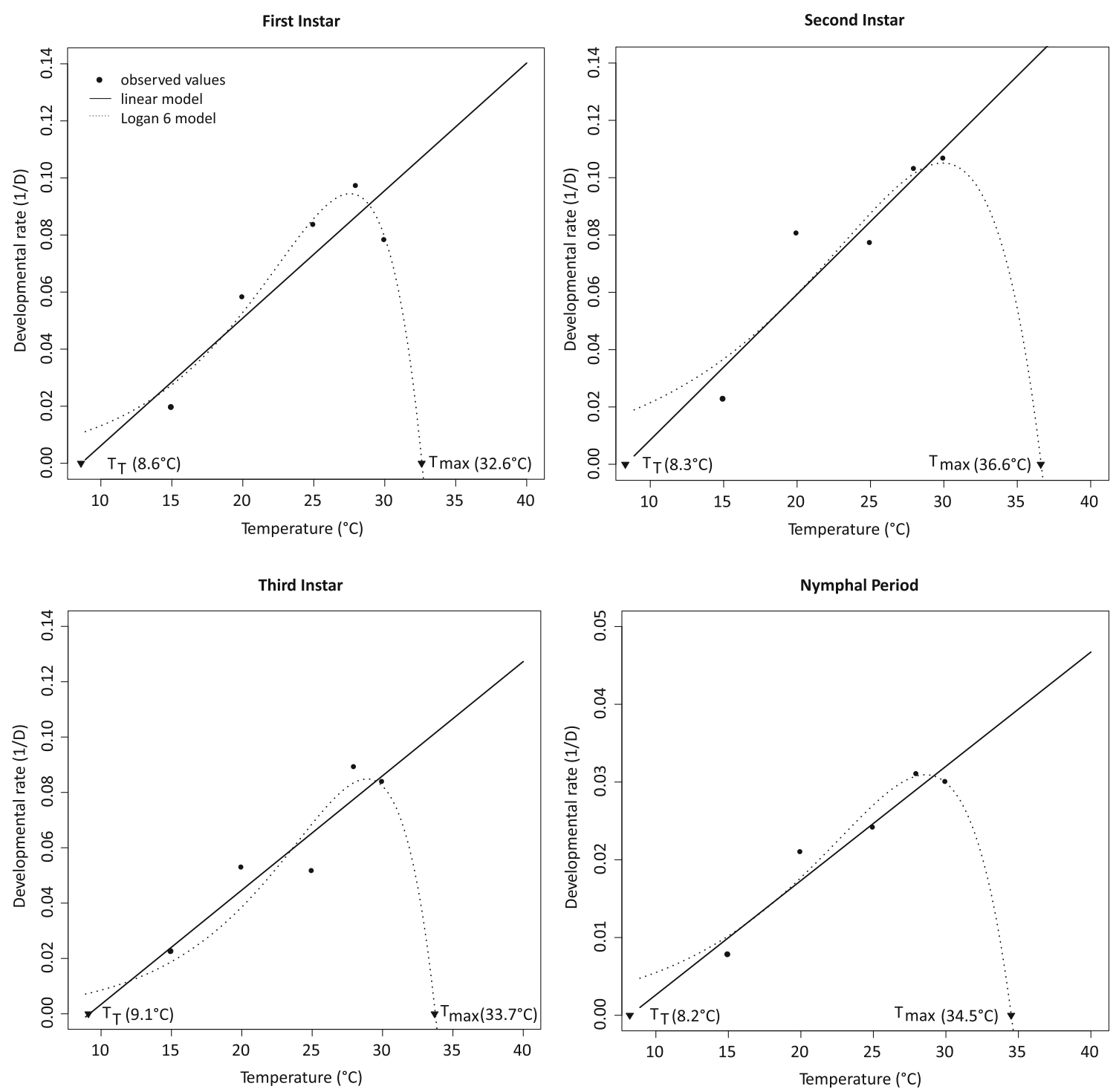

Fig 1 Relationship between developmental rate $(1 / \mathrm{D})$ and temperature $\left({ }^{\circ} \mathrm{C}\right)$ for each developmental stage of Dysmicoccus brevipes on leaves of Itália table grape (Vitis vinifera), at temperatures of $15,20,25,28$, and $30^{\circ} \mathrm{C}(70 \pm 10 \% \mathrm{RH}$ and photophase of $14 \mathrm{~h})$. Dots represent observed rates $\left(T_{\mathrm{T}}\right.$, lower developmental threshold; $T_{\max }$ upper developmental threshold).

Table 3 Upper developmental threshold $\left(T_{\max }\right)$, optimal temperature $\left(T_{\text {opt }}\right)$, and parameters estimated by the Logan 6 model for each developmental stage of Dysmicoccus brevipes on leaves of Itália table grapes (Vitis vinifera), at temperatures of $15,20,25,28$, and $30{ }^{\circ} \mathrm{C}(70 \pm 10 \%$ $\mathrm{RH}$ and photophase of $14 \mathrm{~h}$ ).

\begin{tabular}{llllll}
\hline $\begin{array}{l}\text { Developmental } \\
\text { stage }\end{array}$ & $T_{\max }\left({ }^{\circ} \mathrm{C}\right)$ & $T_{\text {opt }}\left({ }^{\circ} \mathrm{C}\right)$ & $\psi^{\mathrm{a}}$ & $\rho^{\mathrm{b}}$ & $\Delta T^{\mathrm{c}}$ \\
\hline First-instar nymph & 32.62 & 27.57 & 0.07776 & 0.197036 & 5.048199 \\
Second-instar nymph & 36.63 & 30.11 & 0.023693 & 0.144516 & 6.512778 \\
Third-instar nymph & 33.75 & 28.89 & 0.045608 & 0.205007 & 4.853567 \\
Nymphal stage & 34.51 & 28.61 & 0.137967 & 0.169194 & 5.899896 \\
\hline
\end{tabular}

${ }^{\text {a }} \psi$, the maximum developmental rate.

${ }^{\mathrm{b}} \rho$, a constant defining the rate at optimal temperature.

${ }^{\mathrm{c}} \Delta T$, the temperature range over which physiological breakdown becomes the overriding influence. 
Table 4 Estimated number of generations of Dysmicoccus brevipes on different table grape-producing regions of Brazil, based on the lower developmental threshold $\left(T_{T}\right)$ and thermal constant $(K)$.

\begin{tabular}{lll}
\hline City (state code) & $\begin{array}{l}\text { Mean annual temperature } \\
\left({ }^{\circ} \mathrm{C}\right)\end{array}$ & $\begin{array}{l}\text { Number of generations/ } \\
\text { year }^{\mathrm{a}}\end{array}$ \\
\hline Bento Gonçalves (RS) & 17.3 & 3.39 \\
Caxias do Sul (RS) & 16.3 & 3.13 \\
Jales (SP) & 23.8 & 4.77 \\
Maringá (PR) & 21.7 & 4.38 \\
Petrolina (PE) & 26.3 & 5.18 \\
\hline
\end{tabular}

$P E$, Pernambuco; $P R$, Paraná; $R S$, Rio Grande do Sul; $S P$, São Paulo.

a Based on the following formula: $N G=\frac{T}{\left(\frac{k}{T_{m} T_{T}}\right)+P O}$.

${ }^{b}$ Maringá (PR) represents the producing city of Marialva (PR).

showing the influence of the host plant on the mealybug development. The difference in values obtained on different hosts can also be related to the adaptation of populations to the climate conditions in their place of origin, to the difference in the photoperiod used in the experiments (Trudgill et al 2005, Bergant \& Trdan 2006), and to the method used to estimate the developmental thresholds. In addition, developmental time and survival rates might differ if mealybugs are raised on whole leaves or plants. According to Honek (1996), the lower developmental threshold may also decrease with increasing latitude, since species living closer to the tropics have a base temperature (mean $13.7^{\circ} \mathrm{C}$ ) higher than those inhabiting the subtropical (mean $10.5^{\circ} \mathrm{C}$ ) and temperate zones (mean $7.9^{\circ} \mathrm{C}$ ).

According to the values of the lower developmental threshold and the number of degree-days required for $D$. brevipes to complete its development, the estimated number of annual generations for the main table grape-producing regions in Brazil ranged from 3 to 5 . These estimates need to be validated in the field, because in addition to temperature, other factors can influence the establishment and adaptation of populations, such as the humidity, presence of natural enemies, cultural practices in the vineyards (Geiger \& Daane 2001; Cid et al 2010), and host plants (Bertin et al 2013). To date, $D$. brevipes has been reported only in vineyards in the states of Rio Grande do Sul and Pernambuco (Pacheco da Silva et al 2014, 2017); however, our results indicate that the species could likely develop in other table grape-producing regions, like for instance, in the states of Paraná and São Paulo.

We would recommend growers to inspect vineyards for the presence of wet areas on the bark and leaves and also for the presence of sooty mold, which may be an indication of the presence of mealybugs. If mealybugs are detected, the removal of infested leaves and bunches may prevent spreading of mealybugs to other non-infested plants in the vineyard. If necessary, control measures should be applied only to infested plants. Monitoring of the mealybugs in vineyards should be intensified in warmer seasons when mealybugs tend to move from under the bark of the trunk to the new shoots and leaves.

The thermal requirements determined in this study can help in understanding the population dynamics of $D$. brevipes in vineyards, as well as in predicting population peaks, indicating when sampling for population monitoring should be initiated or intensified, or at what time control should be employed. In addition, this information can assist in the optimization of laboratory rearing and in the establishment of future biological control programs, where knowledge of the thermal requirements, together with sampling the population in the field, will allow predicting the most appropriate period for parasitoid release.

Acknowledgments We thank Dr. Janet W. Reid (JWR Associates) for English and technical corrections, Prof. Dr. Wesley Augusto Conde Godoy for assistance with the non-linear model, and the Conselho Nacional de Desenvolvimento Científico e Tecnológico (CNPq, Process No. 130892/2010-6) for granting a scholarship to the first author.

\section{References}

Bates D, Maechler M, Bolker B, Walker S (2015) Fitting linear mixedeffects models using Ime4. J Stat Softw 67:1-48

Ben-Dov Y (1994) A systematic catalogue of the mealybugs of the world (Insecta: Homoptera: Coccoidea: Pseudococcidae and Putoidae) with data on geographical distribution, host plants, biology and economic importance. Intercept, Andover, p 686

Bergant K, Trdan S (2006) How reliable are thermal constants for insect development when estimated from laboratory experiment? Entomol Exp Appl 120:251-256

Bertin A, Bortoli LC, Botton M, Parra JRP (2013) Host plant effects on the development, survival, and reproduction of Dysmicoccus brevipes (Hemiptera: Pseudococcidae) on grapevines. Ann Entomol Soc Am 106:604-609

Cid M, Pereiro S, Cabaleiro C, Segura A (2010) Citrus mealybug (Hemiptera: Pseudococcidae) movement and population dynamics in an arbor-trained vineyard. J Econ Entomol 103:619-630 
Colen KGF, Santa-Cecília LVC, Moraes JC, Reis PB (2000) Efeitos de diferentes temperaturas sobre a biologia da cochonilha pulverulenta Dysmicoccus brevipes (Cockerell, 1893) (Hemiptera: Pseudococcidae). Rev Bras Frutic 22:248-252

Daane KM, Cooper ML, Triapitsyn SV, Walton VM, Yokota GY, Haviland DR, Bentley WJ, Godfrey KE, Wunderlich LR (2008) Vineyard managers and researchers seek sustainable solutions for mealybugs, a changing pest complex. Calif Agric 62:167-176

Daane KM, Almeida RPP, Bell VA, Walker JTS, Botton M, Fallahzadeh M, Mani M, Miano JL, Sforza R, Walton VM, Zaviezo T (2012) Biology and management of mealybugs in vineyards. In: Bostanian NJ, Vincent C, Isaacs R (eds) Arthropod management in vineyards: pests, approaches, and future directions. Springer, Dordrecht, pp 271-307

Flaherty DL, Philips PA, Legner EF, Peacock WL, Bentley WJ (1992) Mealybugs. In: Flaherty DL, Christensen LP, Lanini WT, Marois JJ, Phillips PA, Wilson LT (eds) Grape pest management. University of California, Oakland, pp 159-165

Geiger CA, Daane KM (2001) Seasonal movement and distribution of the grape mealybug (Homoptera: Pseudococcidae): developing a sampling program for San Joaquin Valley vineyards. J Econ Entomol 94: 291-301

González RH, Volosky C (2004) Chanchitos blancos y polillas de la fruta: problema cuarentenarios de la fruta de exportación. Rev Frutic 25:41-62

Groth MZ, Loeck AE, Nornberg SD, Bernardi D, Nava DE (2017) Biology and thermal requirements of Fopius arisanus (Sonan, 1932) (Hymenoptera: Braconidae) reared on Ceratitis capitata eggs (Wiedemann) (Diptera: Tephritidae). Neotrop Entomol 46:554-560

Haddad ML, Parra JRP (1984) Métodos para estimar as exigências térmicas e os limites de desenvolvimento dos insetos. FEALQ, Piracicaba, p 45

Honek A (1996) Geographical variation in thermal requirements for insect development. Eur J Entomol 93:303-312

Hothorn T, Bretz F, Westfall P (2008) Simultaneous inference in general parametric models. Biom J 50:346-363

Ju RT, Zhu HY, Gao L, Zhou XH, Li B (2015) Increases in both temperature means and extremes likely facilitate invasive herbivore outbreaks. Sci Rep 5:15715. https://doi.org/10.1038/srep15715

Logan JA, Wollkind SC, Hoyt SC, Tanigoshi LK (1976) An analytical model for description of temperature dependent rate phenomenon in arthropods. Environ Entomol 5:1133-1140
McKenzie HL (1967) Mealybugs of California with taxonomy, biology, and control of North American species (Homoptera: Coccoidea: Pseudococcidae). University of California Press, Berkeley, p 526

Morandi Filho WJ, Pacheco da Silva VC, Granara de Willink MC, Prado E, Botton M (2015) A survey of mealybugs infesting South-Brazilian wine vineyards. Rev Bras Entomol 59:251-254

Pacheco da Silva VC, Bertin A, Blin A, Germain J-F, Bernardi D, Rignol G, Botton M, Malausa T (2014) Molecular and morphological identification of mealybug species (Hemiptera: Pseudococcidae) in Brazilian vineyards. PLoS One 9(7):e103267. https://doi.org/10.1371/journal. pone. 0103267

Pacheco da Silva VC, Kaydan MB, Malausa T, Germain JF, Palero F, Botton M (2017) Integrative taxonomy methods reveal high mealybug (Hemiptera: Pseudococcidae) diversity in southern Brazilian fruit crops. Sci Rep 7(1):15741. https://doi.org/10.1038/s41598-017-15983-5.

Protas JFS (2016) A dinâmica evolutiva da vitivinicultura brasileira, cenários 2004-2014. Rev Política Agrícola 1:47-54

R Core Team (2016) R: a language and environment for statistical computing. R Foundation for Statistical Computing, Vienna. http://www. R-project.org/

Robinet C, Roques A (2010) Direct impacts of recent climate warming on insect populations. Integr Zool 5:132-142. https://doi.org/10.1111/j. 1749-4877.2010.00196.x

Roy M, Brodeur J, Cloutier C (2002) Relationship between temperature and developmental rate of Stethorus punctillum (Coleoptera: Coccinellidae) and its prey Tetranychus mcdaniali (Acarina: Tetranychidae). Environ Entomol 31:177-187

Santa-Cecília LVC, Souza B, Souza JC, Prado E, Moino Junior A, Fornazier MJ, Carvalho GA (2007) Cochonilhas-farinhentas em cafeeiros: bioecologia, danos e métodos de controle. EPAMIG, Belo Horizonte, p 48

Trudgill DL, Honek A, Li D, van Straalen NM (2005) Thermal time concepts and utility. Ann Appl Biol 146:1-14

Varikou K, Birouraki A, Bagis N, Kontodimas DC (2010) Effect of temperature on the development and longevity of Planococcus ficus (Hemiptera: Pseudococcidae). Ann Entomol Soc Am 103:943-948

Williams DJ, Granara De Willink MC (1992) Mealybugs of Central and South America. CAB International, London, p 635 